\title{
The Role of the Quizizz Application in Making Online Quiz in Japanese Courses for Students of Hospitality Program
}

\author{
Kanah*, Harisal, I Putu Budiarta \\ Tourism Department \\ State Polytechnic of Bali \\ Badung, Indonesia \\ *kanah@pnb.ac.id, harisal@pnb.ac.id, putubudiarta@pnb.ac.id
}

\begin{abstract}
Blended Learning is an easy learning method that combines a variety of ways of presenting, teaching models, and learning styles, introducing various choices of media dialogue between the facilitator and the people who are taught. In learning Japanese in Tourism department, State Polytechnic of Bali, the blended learning method has not prominent to apply. The use of technology in teaching and learning process are supervise on power points presentation, and online technology is not fully maximizing to apply. The Quizizz application in making online quiz for students is used as a tool to measure student learning outcomes in learning Japanese. The use of the Quizizz application in the Japanese language teaching and learning process, especially in the implementation of quiz, aims to make a less interactive atmosphere more enjoyable and this can have an effect on improving student quiz results. The method used is a quantitative and qualitative descriptive approach. This study looks for the percentage level of student questionnaire results before and after using the Quizizz application when they taking the quiz. The results showed that there was an increase in learning outcomes after the use of the Quizizz application in Japanese language learning, especially during quiz, which made many positive things for both lecturers and students, such: it would facilitate Lecturers particularly their time management; a fun learning atmosphere for students; and, the most important thing, it would influence the improvement of students learning.
\end{abstract}

Keywords-quizizz, Japanese quiz, teaching technology, blended learning

\section{INTRODUCTION}

Blended learning combines traditional and electronic learning. Also, it integrates to aspects of web / internet-based learning, video streaming, synchronous and asynchronous audio communication with traditional face-to-face learning. Blended learning is basically creating a learning excellence that is done face to face learning and e-learning. Both Online and elearning in blended learning has become a natural in traditional classroom learning widely, using a face to face learning model [1]. Moreover, blended learning is a simplifying method by combining various presenting methods, teaching models, and learning styles.

Japanese Subject in Tourism Department, State Polytechnic of Bali has not fully applied the Blended Learning method, due to the difficulties using the online technology. In addition, a low network bandwidth would make the teaching and learning process being ineffectiveness. Based on its phenomena, Japanese major is a difficult subject for students, especially it was not an extra-curriculum in their school. It is because the Japanese grammar is different to other languages, esp. Bahasa Indonesia. Furthermore, many unpopular vocabularies become factors, so they do not have passionate about attending the class. This can be seen while they are given a quiz. Quizzes by answering questions on paper showed it does not attract the student's interests. Therefore, making a fun teaching and learning would be an alternative way to change their enthusiasms.

The existence of the Covid-19 pandemic requires to change the learning-teaching process from traditional to virtual methods. Both Students and Lectures are doing TeachingLearning activities from their home by using a number of available platforms in cyberspace/media social. One of them is Quizizz application.

Quizizz application is an online program that can be used for quiz learning. This application is a web tool for creating interactive quiz games that are used in classroom learning activities. The interactive quiz has many types of multiple choices from 4 answer choices to the wrong answer. In addition, images can be added to the background of the questions, so students could be better understood. To access this application, it can easily be downloaded through the Playstore on Smartphone. Moreover, this application can also be accessed directly through the website www.quizizz.com. Through the Quizizz application, teachers would make fun quizzes and use blended learning methods in the teaching and learning process. 
Research on the use of the Quizizz application has been carried out several times, such: research conducted by Purba [2]. This study emphasizes the use of Quizizz learning evaluation in Physical Chemistry courses. The results showed that there was an increase in student learning concentration through the use of Quizizz learning evaluation in Physical Chemistry courses. On the other hand, Aini [3], examines the use of Quizizz learning media for primary and secondary education in Bengkulu. The results showed that Quizizz can produce creative, innovative, and fun learning media so that it needs to be used as a learning medium.

In this study, the Quizizz application was used as a tool to measure student learning outcomes in Japanese language learning. The use of the Quizizz application in the Japanese language teaching and learning process, especially in quiz learning, is expected to be able to make a less interactive atmosphere more enjoyable and this can have an effect on improving student learning outcomes.

Based on this background, this research focuses on the role of the Quizizz application in making quiz in Japanese courses for students of Hospitality Program.

\section{RESEARCH METHODS}

The method used is a quantitative and qualitative descriptive approach. This study looks for the percentage level of student questionnaire results before and after using the Quizizz application when they taking the quiz. It is called descriptive qualitative because this research also collects data from presentations, field notes, personal documents, notes, memos, and other official documents so that the objective of this qualitative research is, namely disclose the empirical reality behind the phenomenon in depth, detail, and thoroughly. Besides that, it is called descriptive because this research tries to explain the role of the Quizizz application in making online quiz in Japanese language learning.

The population in this study were first year students of Hospitality program, who are studying Japanese, while the sample in this study were first year students of the Hospitality program who were taken using the Slovin formula according to Sugiyono [4], namely:

$$
n=\frac{N}{\left(N \cdot d^{2}\right)+1}
$$

$$
\begin{aligned}
& \mathrm{n}=\text { number of samples } \\
& \mathrm{N}=\text { number of population } \\
& \mathrm{d}=\text { sampling error }
\end{aligned}
$$

From five classes of first year students in the Hospitality program, the number of students is 169 students. With a sampling error of $10 \%$ or 0.1 , the number of samples is obtained, namely:

$$
n=\frac{169}{\left(169 .(0.1)^{2}\right)+1}=62.8252 \approx 63
$$

So the number of samples taken in this study were 63 students of the hospitality study program.

After taking the sample with the Slovin formula, there are 63 students from a total of 169 students who will be the samples. To determine the number of students to be taken in each class, the next sampling technique used was purposive sampling. Purposive sampling is a sampling technique that is done deliberately. It means that the samples was chosen deliberately, so that the criteria for the sample obtained were in accordance with the research being carried out, then approximately 13 students who met the $100 \%$ attendance standard were taken each, so that students who were used as data sources could be obtained validly and completely.

To complement the research, the Data Collection Techniques are drawing out as follows:

1) Observation: This research uses complete participatory observation, to object the data source, in this case the Researcher is a Japanese lecturer/Teacher, and the Data source is the quiz results of the Quizizz application.

2) Interview: Interviewing students for those who applying the Quizizz application to their assignment online quizzes.

3) Documentation: The documentation in this study is the results of the quiz using the Quizizz application, and other documents by pictures to prove that the role of the Quizizz application in making online quizzes in Japanese course/class works.

\section{RESULTS AND DISCUSSION}

Quizizz application brings benefit for online teachers to provide information. In addition, the students' score after completed the quizzes could be a references for teachers/lecturers to know their disciplines due to the estimated time for answering each questions on the quizzes. Moreover, its visualization attracts the students' interest. Additional features like memes and quotes encourage students to complete Japanese quiz.

In Blended Learning, Implementation technology such Quizizz application is one of solution nowadays, due to the Covid-19 Pandemic. Besides, it is very useful, especially assessing students' skills in Japanese. Furthermore, parents can also monitor the learning outcomes of their children through the Quizizz application.

On the Quizizz platform, the first thing that is displayed is the choice of using the application. There are two choices for its use, namely: FOR LEARNING and FOR WORK. Then, three choices of user identity at registration, they are TEACHERS, STUDENTS, and PARENTS 


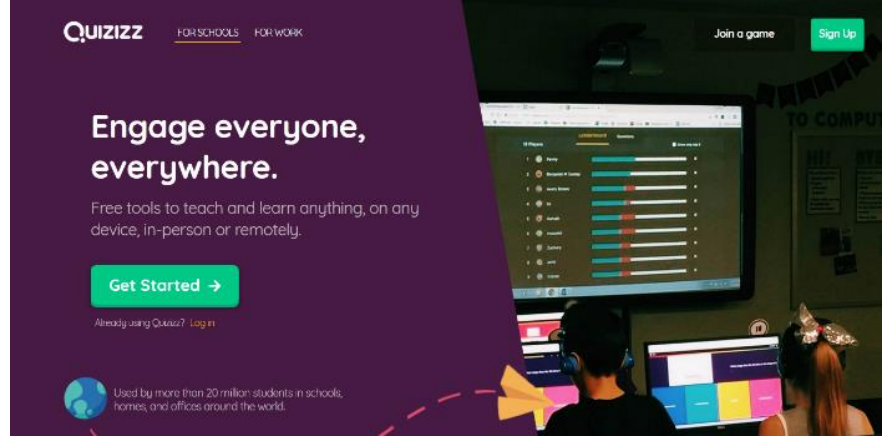

Fig. 1. Quizizz page display.

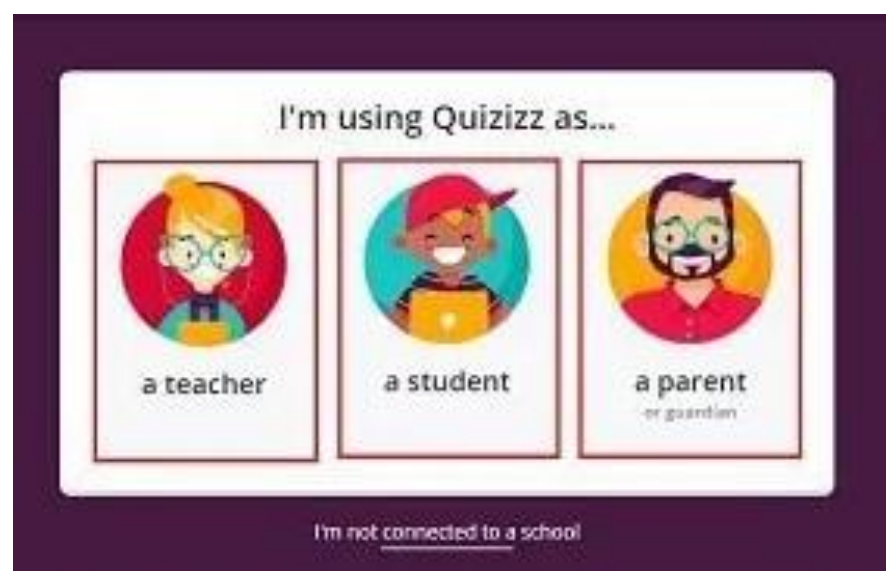

Fig. 2. Display user options.

\section{A. Making Japanese Online Quiz with Quizizz Application}

Making Japanese Online Quiz with Quizizz application is only for 'TEACHER' account users. Therefore, make sure that the user account is a 'teacher'.

In making quizzes, there are several steps you might be in, such as:

1) Name the quiz theme first, and specify the class which relevant to the quiz: based on the learning subject.

2) Select the type of question that will be used for each question to be made: There are several types of questions to choose, they are:

- Multiple Choice, a question type with a maximum of five answer choices, and one correct answer.

- Checkbox, a question type with a maximum of five answer choices with several correct answers by putting a check mark in the provided box for each answer.

- Fill the Blank, is a question type to complete the questions that should be answered by students. In making the answer keys, this type of question provides four alternative answers to the right one. Also, dot and comma signs are greatly influencing the correct of Students' answers.
- Poll, is a question type by choosing a maximum of five answers, rather than one.

- Open-Ended, is a question type without an answer key. This is suitable for expressing students' opinions about the questions asked.

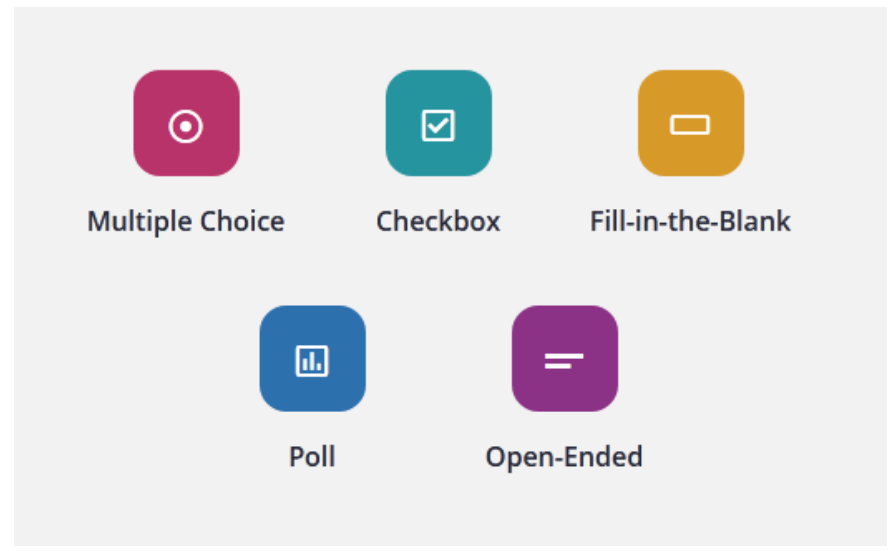

Fig. 3. Types of questions in the Quizizz application.

3) Set the time to answer questions: In the Quizizz application, there is such a spot to set the estimated time for students by answering each questions later. The time given starts from 5 seconds to 15 minutes for each question, in order to maintain the time management, so any cheating activities could be minimalized while accomplish the quizzes, especially on paper quiz.

4) After making and arranging questions: the next step is inserting a picture for the quiz title in the 'add image' Menu, entering the language, choosing a grade level, and setting the use of this quiz for personal or public user.

5) Then, check the general settings for some features to keep Quiz is going well: with no students' cheating assumptions anymore.

\begin{tabular}{|l|}
\hline General settings \\
$\begin{array}{l}\text { Student attempts } \\
\text { How many times can students take this quiz? }\end{array}$ \\
\hline $\begin{array}{l}\text { Name factory } \\
\text { Students can only use fun Quizizz-generated names }\end{array}$ \\
\hline $\begin{array}{l}\text { Show answers in-game } \\
\text { Show students the correct answers after each } \\
\text { question }\end{array}$ \\
\hline $\begin{array}{l}\text { Show answers post-game } \\
\text { Allow students to review questions and } \\
\text { answers at the end }\end{array}$ \\
\hline
\end{tabular}

Fig. 4. General settings. 
Last, the quiz is ready for students and give a link to let Students join the quizizz. Afterward, give them the game code which provided by the web. It will be different every time while the quiz start. It is preventing the quiz being accessed by irresponsible people.

\section{B. Questionnaire Results Pre-Learning Japanese With Quizizz Application}

The results of the pre and post Japanese learning questionnaire with the Quizizz application for 63 respondents, showed that the questionnaire provided was realistic and could be used as a tool for conducting research. Of the 63 responses, the number of respondents from A class was $20.6 \%$, B class was $19.1 \%$, C class was $19.1 \%$, D class was $20.6 \%$, and E class was $20.6 \%$, so that the total is $100 \%$. Furthermore, of the 63 responses, $63.5 \%$ were female respondents, while $36.5 \%$ were male respondents.

In the Japanese pre-learning questionnaire with the Quizizz application, there are 12 questions with answer choices that strongly agree, agree, disagree, and strongly disagree. This questioner is distributed via google form. This is due to the Covid-19 pandemic which makes students learn from home.

Following are students' responses to pre-learning Japanese questioners with the Quizizz application, namely:

TABLE I. AVERAGE RESPONSES OF PRE-QUIZIZZ RESPONDENTS

\begin{tabular}{|c|c|c|c|c|c|}
\hline \multirow{2}{*}{ NO } & \multirow{2}{*}{ QUESTIONS } & \multicolumn{4}{|c|}{ SCALE } \\
\hline & & $S A$ & $A$ & $D A$ & $S D A$ \\
\hline 1 & $\begin{array}{l}\text { I have studied Japanese at a } \\
\text { school / course }\end{array}$ & 16 & 26 & 10 & 11 \\
\hline 2 & $\begin{array}{l}\text { I am interested in learning } \\
\text { Japanese }\end{array}$ & 29 & 34 & 0 & 0 \\
\hline 3 & $\begin{array}{l}\text { I like learning Japanese } \\
\text { because there are games }\end{array}$ & 17 & 39 & 7 & 0 \\
\hline 4 & $\begin{array}{l}\text { I often use smart phones in } \\
\text { class }\end{array}$ & 4 & 25 & 30 & 4 \\
\hline 5 & $\begin{array}{l}\text { I like to use smart phones in } \\
\text { class just to open social } \\
\text { media }\end{array}$ & 1 & 8 & 39 & 15 \\
\hline 6 & $\begin{array}{l}\text { I prefer to use a smart phone } \\
\text { to help me learn Japanese in } \\
\text { class }\end{array}$ & 21 & 31 & 11 & 0 \\
\hline 7 & $\begin{array}{l}\text { I was excited to take the quiz } \\
\text { during Japanese lessons }\end{array}$ & 22 & 40 & 1 & 0 \\
\hline 8 & $\begin{array}{l}\text { answering Quiz questions on } \\
\text { a single sheet of paper is very } \\
\text { tedious }\end{array}$ & 8 & 19 & 33 & 3 \\
\hline 9 & $\begin{array}{l}\text { Answering quiz questions } \\
\text { with manual scripts is time- } \\
\text { consuming }\end{array}$ & 3 & 30 & 28 & 2 \\
\hline 10 & $\begin{array}{l}\text { Taking quizzes online could } \\
\text { be a lot of fun }\end{array}$ & 18 & 30 & 13 & 2 \\
\hline 11 & $\begin{array}{l}\text { I would be more eager to do } \\
\text { quizzes if they were done in } \\
\text { application form }\end{array}$ & 16 & 37 & 10 & 0 \\
\hline 12 & $\begin{array}{l}\text { I will be very excited if I can } \\
\text { take advantage of technology } \\
\text { in learning, especially in } \\
\text { Japanese }\end{array}$ & 28 & 31 & 4 & 0 \\
\hline Avera & & 15,3 & 29,2 & 15,5 & 3,08 \\
\hline
\end{tabular}

Based on the table above, it can be concluded that all respondents tend to agree with the use of the Quizizz application in Japanese learning. The combination of traditional learning and technology will be very enjoyable for students. In addition, lecturers also find it easier to teach.

Therefore, based on the results of the pre-learning Japanese questionnaire with the Quizizz application above, learning with the Quizizz application will begin to be tested on students to find out the extent of changes that have occurred in the Japanese learning process in the classroom.

\section{Questionnaire Results Post-Learning Japanese with Quizizz Application}

In the post-learning Japanese questioner with the Quizizz application, there are 12 questions with answer choices that strongly agree, agree, disagree, and strongly disagree. This questioner is distributed via google form. This is due to the Covid-19 pandemic which makes students learn from home.

Following are students' responses to post-learning Japanese questioners with the Quizizz application, namely:

TABLE II. AVERAGE RESPONSES OF POST-QUIZIZZ RESPONDENTS

\begin{tabular}{|c|c|c|c|c|c|}
\hline \multirow{2}{*}{ NO } & \multirow{2}{*}{ QUESTIONS } & \multicolumn{4}{|c|}{ SCALE } \\
\hline & & $S A$ & $A$ & $D A$ & $S D A$ \\
\hline 1 & $\begin{array}{l}\text { Online quizzes are more } \\
\text { interesting than manual } \\
\text { quizzes }\end{array}$ & 12 & 41 & 8 & 2 \\
\hline 2 & Taking online quizzes is fun & 10 & 42 & 10 & 1 \\
\hline 3 & $\begin{array}{l}\text { quizzes with the Quizizz } \\
\text { application are very } \\
\text { interesting and useful }\end{array}$ & 24 & 33 & 6 & 0 \\
\hline 4 & $\begin{array}{l}\text { I am even more excited about } \\
\text { taking Japanese classes } \\
\text { because of the Quizizz } \\
\text { application }\end{array}$ & 12 & 39 & 12 & 0 \\
\hline 5 & $\begin{array}{l}\text { I was helped in learning } \\
\text { Japanese with the Quizizz } \\
\text { application }\end{array}$ & 11 & 38 & 13 & 1 \\
\hline 6 & $\begin{array}{l}\text { The Quizizz application } \\
\text { made me understand more } \\
\text { about Japanese usage }\end{array}$ & 9 & 31 & 23 & 0 \\
\hline 7 & $\begin{array}{l}\text { The contents in the Quizizz } \\
\text { application are complete }\end{array}$ & 10 & 41 & 12 & 0 \\
\hline 8 & $\begin{array}{l}\text { Taking quizzes using the } \\
\text { Quizizz application saves } \\
\text { more time studying } \\
\text { compared to using manuals }\end{array}$ & 20 & 36 & 7 & 1 \\
\hline 9 & $\begin{array}{l}\text { I can do quizzes with the } \\
\text { Quizizz application outside } \\
\text { of class }\end{array}$ & 19 & 40 & 5 & 0 \\
\hline 10 & $\begin{array}{l}\text { I can take online classes } \\
\text { using the Quizizz application }\end{array}$ & 13 & 47 & 4 & 0 \\
\hline 11 & $\begin{array}{l}\text { I can use the Quizizz } \\
\text { application not only for } \\
\text { taking quizzes, but for } \\
\text { studying }\end{array}$ & 16 & 38 & 9 & 0 \\
\hline 12 & $\begin{array}{l}\text { Quizizz application helps me } \\
\text { to promote "Green Tourism", } \\
\text { namely by reducing paper } \\
\text { usage }\end{array}$ & 37 & 26 & 1 & 0 \\
\hline Aver & & 16,1 & 37,7 & 9,2 & 0,4 \\
\hline
\end{tabular}


Based on the table above, it can be concluded that from all respondents, they tend to agree that learning Japanese using the Quizizz application really helps them increase their creativity in learning so that it also impacts the quiz scores. Beside that, students are very helpful in creating enthusiasm for learning by using the Quizizz application, and it is proven that the combination of traditional learning and technology is very enjoyable for students. In the other hand, they can also help promote the 'Green Tourism' program, which is reducing paper use.

\section{Role of Quizizz Applications in Japanese Language Learning}

Quizizz applications plays an important role in Japanese courses in the Department of Tourism, State Polytechnic of Bali. It is because the use of this application has several advantages compared to other applications, as follows:

1) Multi-languages: In the Quizizz application, the majority is English, so students can learn both English and Japanese.

2) Including four language skills: The Quizizz application also includes four skills in language: listening, writing, reading, and speaking.

3) Time efficiency: Time efficiency is the most important thing in Quizizz. The estimated time set in each question, so students could be disciplined.

4) Cheating Subtraction: Due to time limits, randomized questions, and no answer keys after completing the quiz, makes students difficult to cheat off, open any books or references, and so on.

5) Correcting answers: While accomplishing the Quiz, students have extra time to review their incorrect answers before time is up if they could answer the questions correctly and quickly.

6) Fair Learning Skill Competition: students can see their grades each other, and it stimulates their adrenalin to compete and increase points to answer the right questions without cheating.

7) Quick results: After all quiz questions have been answered, the results will show the students' grade with ranking percentages, so they could monitor it respectively. On the other hand, this can be an advantage for teachers/lecturers because find out the results of the quiz immediately without need an extra time by reviewing the Students' results.

8) Having a progress chart: The Quizizz application has a progress chart for Students' assignment problem as skills measurement.

9) Safe storage: After completing the quiz, the Quizizz application as a media storage to save the quiz results to be viewed at any time if needed.
10) Reporting to parents: The quiz results can be directly reported to parents via 'EMAIL TO PARENTS' feature. It is placed on the right side of the Students' quizzes results, so t it can be directly clicked anytime.

11) Having memes: Memes can be added by the teachers/lectures using any attractive images and wise words, aimed to support and praise students for their results.

12) Full colors: Visualization is one of the most important thing to make fun learning in Japanese Class. The Quizizz application has a very colorful looks that live the classroom atmosphere attract the students' interest about quizzes.

\section{CONCLUSION}

In Covid-19 pandemic nowadays, the teachers/Lecturers required to change the learning-teaching process from traditional to virtual methods. They should create to find some fun learning variations, especially quizzes.

Quizizz application is one of solution to facilitate teachers in Japanese major. Furthermore, it is a practical learning methods, having learning resources completely and utilizing multimedia Revolution 4.0, has showed the implementation became various and interesting. Having all documentations in learning activities and resources are taken while progress and saved automatically. Fascinating design of learning material attract the Students' interest to learn more fun. Also, other media to create teaching and learning process such as playing using various educational games, videos, and learning resource are available. Besides, parents could monitor student learning activities through the website or via mobile phone.

The use of the Quizziz application in Japanese quizzes has resulted in an increasing learning outcomes after the use of the Quizizz application in Japanese language learning, especially during quiz, which made many positive things for both lecturers and students, such: it would facilitate Lecturers particularly their time management; a fun learning atmosphere for students; and, the most important thing, it would influence the improvement of students learning.

\section{REFERENCES}

[1] S.B. Sjukur, "Pengaruh blended learning terhadap motivasi belajar dan hasil belajar siswa tingkat SMK". Jurnal Pendidikan Vokasi, Vol 2, No. 3. 2012 .

[2] L.S.L. Purba, "Peningkatan Konsentrasi Belajar Mahasiswa Melalu Pemanfaatan Evaluasi Pembelajaran Quizizz Pada Mata Kuliah Kimia Fisika I". JDP. 12(1): 29, 2019.

[3] Y.I. Aini, Pemanfaatan Media Pembelajaran Quizizz Untuk Pembelajaran Jenjang Pendidikan Dasar Dan Menengah Di Bengkulu. 2019

[4] Sugiyono, Metode Penelitian Kualitatif Kuantitatif dan R\&D. Bandung: Alfabeta. 2010 